Article

\title{
Supplementing Dairy Ewes Grazing Low Quality Pastures with Plant-Derived and Rumen-Protected Oils Containing Eicosapentaenoic Acid and Docosahexaenoic Acid Pellets Increases Body Condition Score and Milk, Fat, and Protein Yields
}

\author{
Quang V. Nguyen ${ }^{1,2}$, Hung V. Le ${ }^{1,3}$, Don V. Nguyen ${ }^{1,3}$, Peter Nish ${ }^{4}$, John R. Otto ${ }^{1}$, \\ Bunmi S. Malau-Aduli ${ }^{5}$, Peter D. Nichols ${ }^{1,6}$ and Aduli E. O. Malau-Aduli 1,*(D) \\ 1 Animal Genetics and Nutrition, Veterinary Sciences Discipline, College of Public Health, Medical and \\ Veterinary Sciences, Division of Tropical Health and Medicine, James Cook University, Townsville, \\ Queensland 4811, Australia; quang.nguyen2@my.jcu.edu.au (Q.V.N.); vanhung.le@my.jcu.edu.au (H.V.L.); \\ donviet.nguyen@my.jcu.edu.au (D.V.N.); john.otto@jcu.edu.au (J.R.O.); Peter.Nichols@csiro.au (P.D.N.) \\ College of Economics and Techniques, Thai Nguyen University, Thai Nguyen 252166, Vietnam \\ National Institute of Animal Science, Thuy Phuong, Bac Tu Liem, Hanoi 129909, Vietnam \\ TasHerd Pty Limited, P.O. Box 68, Hadspen TAS 7290, Australia; peter.nish@tasherd.com.au \\ 5 College of Medicine and Dentistry, Division of Tropical Health and Medicine, James Cook University, \\ Townsville, Queensland 4811, Australia; bunmi.malauaduli@jcu.edu.au \\ 6 CSIRO Oceans \& Atmosphere, P.O. Box 1538, Hobart TAS 7001, Australia \\ * Correspondence: aduli.malauaduli@jcu.edu.au; Tel.: +61-747-815-339
}

Received: 12 November 2018; Accepted: 15 December 2018; Published: 19 December 2018

Simple Summary: This study evaluated the lactation performance and body condition scores of purebred Awassi and Awassi $\times$ East Friesian crossbred dairy ewes grazing low quality pastures and supplemented with diverse plant-derived oil enriched pellets under on-farm management conditions. The origin and treatment of eicosapentaenoic acid (EPA) and docosahexaenoic acid (DHA) to get the rumen protected EPA + DHA treatment was based on a modification of the microencapsulation of oil droplets in a protein-aldehyde matrix procedure. The results demonstrated that supplementation with rumen (EPA + DHA) and oil-infused pellets improved milk, fat, and protein yields by approximately $30 \%, 13 \%$, and $31 \%$ respectively, and crossbred ewes produced more milk than purebreds. These results are very useful for dairy sheep producers in improving ewe lactation performance, milk quality, and body condition score under low quality pasture grazing conditions.

Abstract: The Australian dairy sheep industry is small and mostly based on a natural grass grazing system, which can limit productivity. The current study tested different plant oil-infused and rumen protected polyunsaturated fats and their interactions with sire breeds to improve lactation traits and body condition scores (BCS) of ewes grazing low quality pastures. It was hypothesised that supplementing lactating ewe's diets with plant-derived polyunsaturated oils would improve milk production and composition without compromising BCS. Sixty ewes ( $n=10$ /treatment) in mid-lactation, balanced by sire breed, parity, milk yield, body condition score, and liveweight, were supplemented with: (1) control: wheat-based pellets without oil inclusion; wheat-based pellets including; (2) canola oil (CO); (3) rice bran oil (RBO); (4) flaxseed oil (FSO); (5); safflower oil (SFO); and (6) rumen protected marine oil containing eicosapentaenoic acid and docosahexaenoic acid (RPO). Except for the control group, all supplementary diets included the same level of $50 \mathrm{~mL} / \mathrm{kg} \mathrm{DM}$ of oil and all diets were isocaloric and isonitrogenous. Experimental animals were grazed in the same paddock with ad libitum access to pasture, hay, and water during the 10-week study. RPO was the most effective diet that enhanced milk, fat, and protein yields by approximately $30 \%, 13 \%$, and $31 \%$, 
respectively $(p<0.0001)$. A significant increase in milk production was also observed with CO, RBO, and SFO treatments $(p<0.0001)$. Breed significantly influenced animal performance with higher milk yields recorded for crossbred Awassi $\times$ East Friesian $(\mathrm{AW} \times \mathrm{EF})(578 \mathrm{~g} /$ day $)$ vs. purebred Awassi (452 g/day) $(p<0.0001)$. This study provides empirical evidence for the use of rumen-protected and plant-derived oil-infused pellets as supplements under low quality pasture grazing conditions to improve the production performance of purebred Awassi and crossbred AW $\times$ EF ewes.

Keywords: PUFA; oils; body condition score; sheep milk composition; supplementation; canola; flaxseed; safflower; rice bran

\section{Introduction}

Although previously published studies have demonstrated that sheep milk has more nutritional value compared to cow milk [1,2], the contribution of milk derived from sheep to national milk production in Australia is relatively low. As of 2013, there were 13 commercial farms producing 550,000 litres of milk annually [3] compared to 9 billion litres of milk produced by dairy cows nationwide [4]. Milk yield and composition are influenced by various factors, including diet, breed, age, management practices, health, and the environment [5-7]. Dietary supplementation with fat is considered as an effective tool to improve milk yield and alter milk composition $[8,9]$. Plant derived oils are a potential source of dietary fat and have been used in ruminant feeds to increase the energy density of diets and modify the milk fatty acid profile $[7,10,11]$, with the aim of increasing $n-3$ long-chain $(\geq \mathrm{C} 20)$ polyunsaturated fatty acids (n-3 LC-PUFA) in dairy products. This is because high consumption of n-3 LC-PUFA in humans has been demonstrated to inhibit adipogenic, diabetogenic, atherogenic [12], inflammatory [13,14], and carcinogenic [15] diseases and lower the risk of developing Alzheimer's disease [16]. A number of authors have demonstrated that while dietary fat supplements can enhance milk yield [17-20], it is accompanied by a decrease in milk fat and protein composition because of the negative correlation between milk solid concentration and milk yield $[7,21]$. This could reduce the income of the producers as milk is generally traded based on total milk solids. For this reason, the use of fats as dietary sources to improve the milk yield of sheep used for commercial milk harvesting within Australia is not widely undertaken and is mostly applied as a supplement only during the dry seasons when pasture quality and quantity are low, in order to increase the energy intake of lactating animals [22].

To our current knowledge, studies on the effect of dietary supplementation with rice bran, canola, and safflower oils on milk yield and composition have only been conducted with dairy cows $[19,23,24]$ and goats [25], but not dairy ewes. The effects of supplementation with flaxseed on animal performance and milk fatty acid profiles have been studied with dairy ewes, however, these investigations supplemented flaxseed either as whole or extruded grain [26-28]. In addition, there has been a paucity of studies that have examined the effects of varying dietary supplementation on lactation and liveweight traits in grazing dairy ewes of different genetic backgrounds under the same management and feeding regime.

The major objective of the current work was to fill these knowledge gaps by comparing the lactation performance, milk composition, and body condition score of dairy ewes in mid lactation grazing low quality pastures and supplemented with canola, rice bran, flaxseed, safflower, and rumen protected oil-infused pellets. It was hypothesised that supplementing grazing dairy ewes with oils of different plant-derived and marine origins will have different effects on milk yield, milk composition, and body condition score. 


\section{Materials and Methods}

\subsection{Animal Ethics}

The use of animals and procedures performed in this study were all approved by the University of Tasmania Animal Ethics Committee (Permit No A0015657).

\subsection{Animal Management and Experimental Design}

Sixty lactating Awassi and crossbred Awassi $\times$ East Friesian ewes in mid-lactation, located in the South East of Tasmania (Grandvewe Cheeses Farm, Birchs Bay, Woodbridge, Tasmania, Australia), were included in a 10-week feeding trial where the ewes were kept in the same paddock and had ad libitum access to local natural velvet tussock grass, hay, and water. The experimental animals were allocated to six dietary treatments with each group balanced for liveweight, breed, parity, body condition score (BCS), and milk yield. Treatments consisted of (1) commercial wheat-based pellets without oil inclusion (control); wheat-based pellets infused with $50 \mathrm{~mL} / \mathrm{kg} \mathrm{DM}$ of (2) canola (CO); (3) rice bran (RBO); (4) flaxseed (FSO); (5) safflower (SFO), and (6) rumen protected EPA + DHA (RPO) oils, as represented in Table 1. All treatments were isocaloric and isonitrogenous (Table 2). Each ewe was fed $1 \mathrm{~kg}$ /day of the supplemented pellet individually in the milking parlour during milking time over a 10-week period with an initial two-week adjustment period, followed by an 8-week experimental period. In the first two weeks of the adjustment period, commercial pellets (control) for each treatment group were increasingly substituted at $100 \mathrm{~g} /$ day by the experimental diets, CO, RBO, FSO, SFO, and RPO, until the attainment of $1 \mathrm{~kg} /$ day on day 10 was achieved. Ewes were milked in the mornings at $0600 \mathrm{~h}$ and individual milk yield was electronically recorded by the La Laval platform using De Laval's Alpro Herd Management System software version 6.54 (De Laval, Tumba, Sweden).

Table 1. Ingredient composition of the experimental pellets ${ }^{a}$.

\begin{tabular}{ccccccc}
\hline Items & Control & CO & RBO & FSO & SFO & RPO \\
\hline Ingredient, g/kg & & & & & & \\
Wheat & 585 & 545 & 535 & 465 & 535 & 530 \\
Paddy rice & 210 & 210 & 220 & 280 & 210 & 215 \\
Lupins & 148 & 148 & 148 & 148 & 148 & 148 \\
Canola oil, ml/kg & - & 50 & - & - & - & - \\
Flaxseed oil, ml/kg & - & - & - & 50 & - & - \\
Safflower oil, ml/kg & - & - & - & - & 50 & - \\
Rice bran oil, ml/kg & - & - & 50 & - & - & - \\
EPA + DHA, ml/kg & - & - & - & - & - & 50 \\
Ammonium sulphate & 12.6 & 12.6 & 12.6 & 12.6 & 12.6 & 12.6 \\
Salt & 10 & 10 & 10 & 10 & 10 & 10 \\
Limestone & 20.9 & 20.9 & 20.9 & 20.9 & 20.9 & 20.9 \\
Sheep premix & 1 & 1 & 1 & 1 & 1 & 1 \\
Acid buff & 6.25 & 6.25 & 6.25 & 6.25 & 6.25 & 6.25 \\
Sodium bicarbonate & 6.25 & 6.25 & 6.25 & 6.25 & 6.25 & 6.25 \\
\hline a Canola oil (CO); rice bran oil (RBO); flaxseed oil (FSO); safflower oil (SFO); rumen-protected oil (RPO).
\end{tabular}


Table 2. Nutrient compositions ${ }^{\mathrm{a}}$ of basal and experimental diets ${ }^{\mathrm{b}}$.

\begin{tabular}{ccccccccc}
\hline Component (\% DM) & Pasture & Hay & Control & CO & RBO & FSO & SFO & RPO \\
\hline DM & 96.5 & 95.5 & 91.5 & 93.0 & 91.6 & 90.0 & 91.7 & 91.6 \\
OM & 90.5 & 97.3 & 92.2 & 93.3 & 92.7 & 91.0 & 91.8 & 92.0 \\
Ash & 9.5 & 2.7 & 7.8 & 6.7 & 7.3 & 9.0 & 8.2 & 8.0 \\
ADF & 45.5 & 37.6 & 10.6 & 7.1 & 8.1 & 9.7 & 9.0 & 8.5 \\
NDF & 69.9 & 68.3 & 30.0 & 21.8 & 19.4 & 23.3 & 23.9 & 22.0 \\
EE & 1.4 & 1.2 & 3.3 & 5.7 & 5.2 & 5.4 & 5.0 & 5.1 \\
CP & 4.7 & 4.3 & 14.6 & 14.0 & 14.7 & 14.6 & 14.5 & 15.6 \\
TDN & 48.5 & 54.1 & 73.4 & 75.9 & 75.2 & 74.1 & 74.5 & 74.9 \\
ME, MJ/kg DM & 7.1 & 8.1 & 11.7 & 12.2 & 12.0 & 11.8 & 11.9 & 12.0 \\
\hline
\end{tabular}

a Dry matter (DM), organic matter (OM), acid detergent fibre (ADF), neutral detergent fibre (NDF), ether extract (EE), crude protein (CP), total digestible nutrients (TDN) and metabolisable energy (ME); ${ }^{\mathrm{b}}$ Canola oil (CO), rice bran oil (RBO), flaxseed oil (FSO), safflower oil (SFO), rumen-protected oil (RPO).

\subsection{Feed Intake and Body Condition Score}

The amount of offered pellets and residuals were weighed daily to calculate feed intake. Weekly feed samples were collected and stored at $-20^{\circ} \mathrm{C}$ for subsequent chemical analysis. Body condition score (BCS) was subjectively evaluated at weekly intervals on a scale of 1-5 [29] by the same evaluator to ensure consistency and repeatability.

\subsection{Milk Sample Analyses}

Weekly milk samples from each animal were bulked from daily milkings at $0600 \mathrm{~h}$ and stored in labelled plastic vials containing bromopol blue preservative at $4{ }^{\circ} \mathrm{C}$ before sending the samples off to Hadspen for compositional analysis at the officially contracted herd recording laboratory-TasHerd Pty Ltd., (Hadspen, Tasmania, Australia). Fourier transformed infrared spectrometry (Bentley Fourier Transform Spectrometer, Chaska, MN, USA) was used to quantify milk composition. This system uses Bentley Flow Cytometry to measure the somatic cell count, while the Bentley Fourier Transform Spectrometer measures somatic cell count, milk fat, protein, and lactose based on an official laboratory analysis method [30]. The equation from Mavrogenis and Papachristoforou [31] was used to calculate the fat-corrected milk (FCM):

$$
6 \% \mathrm{FCM}=\mathrm{M}(0.453+0.091 \mathrm{~F})
$$

where " $\mathrm{F}$ " is the percentage of fat and " $\mathrm{M}$ " is the milk yield (kg).

\subsection{Chemical Analysis of Experimental and Basal Diets}

Before analysing dry matter (DM), ash, and chemical composition, samples of the basal and experimental diets were dried in a fan-forced oven at a constant temperature of $65{ }^{\circ} \mathrm{C}$ and subsequently ground through a $1 \mathrm{~mm}$ sieve using a Thomas Model 4 Laboratory Mill (Thomas Scientific, Swedesboro, $\mathrm{NJ}, \mathrm{USA})$. DM content was determined by placing the ground samples at $150^{\circ} \mathrm{C}$ in an oven for $24 \mathrm{~h}$ to remove moisture. The samples were combusted in a furnace set at $600{ }^{\circ} \mathrm{C}$ for $8 \mathrm{~h}$ to determine ash content. Neutral detergent fibre (NDF) and acid detergent fibre ADF were quantified using an ANKOM220 fibre analyser, while an ANKOM ${ }^{\mathrm{XT15}}$ fat/oil extractor (ANKOM Technology Corp., Macedon, NY, USA) was used to measure ether extract. The crude protein percentage was calculated based on the value of nitrogen that was determined using a Thermo Finnigan EA 1112 Series Flash Elemental Analyser (Thermo Fisher Scientific, Waltham, MA, USA). Table 2 shows the nutritional composition of the experimental diets.

\subsection{Data and Statistical Analysis}

All data were analysed using 'Statistical Analysis System' software [32]. Initial descriptive summary statistics were computed with means, standard errors, and minimum and maximum values scrutinised for data entry errors and outliers. The data were then subjected to general linear model 
(PROC GLM) analysis, with different oil supplementation, sire breed, week of supplementation, and their interactions fitted as fixed effects and feed intake, milk yield, milk composition, and body condition score as dependent variables. The level of significance threshold was $p<0.05$ and differences between means were established using Duncan's multiple range and Turkey's probability pairwise comparison tests. The final statistical model used for the analysis was:

$$
Y i j k=\mu+S_{i}+D_{j}+W_{k}+(S B D)_{i j}+(S B W)_{i k}+(D W)_{j k}+e_{i j k}
$$

where $Y_{i j k}$ is the dependent variable, $\mu$ is the overall mean, SB, D, and $W$ are the fixed effects of sire breed, diet, and week of supplementation, respectively, brackets represent second-order interactions, and $\mathrm{e}_{\mathrm{ijk}}$ is the error term.

\section{Results}

The results of this study suggest that dietary treatments significantly influenced feed intake of grazing dairy ewes $(p<0.0001$; Table 3$)$, with DM intakes being greatest in the control group, followed by the RBO, SFO, CO, RPO, and FSO groups, respectively. Estimated intake of OM, ADF, NDF, and CP followed a similar pattern to DMI, with the greatest intakes observed in the control group, except the intake of EE, which was greatest in the RBO group (41 g/day). Breed and its interaction with supplementation had no significant effect on intake (DMI), and was therefore excluded from Table 3.

Table 3. Least square means and standard errors (LSM \pm SEM) of experimental feed intake ${ }^{\text {a }}$ (g/head/day).

\begin{tabular}{|c|c|c|c|c|c|c|c|}
\hline Items & Feed Intake & DMI & OM & ADF & NDF & EE & $\mathrm{CP}$ \\
\hline \multicolumn{8}{|l|}{ Treatment $^{\mathrm{b}}(\mathrm{T})$} \\
\hline Control & $885.5^{\mathrm{a}}$ & $810.3^{a}$ & $741.4^{\mathrm{a}}$ & $85.9^{a}$ & $243.1^{\mathrm{a}}$ & $26.7^{\mathrm{e}}$ & $118.3^{a}$ \\
\hline $\mathrm{CO}$ & $751.3^{c}$ & $698.7^{c}$ & $651.9^{b}$ & $49.6^{\mathrm{e}}$ & $152.3^{d}$ & $39.8^{b}$ & $97.8^{\mathrm{e}}$ \\
\hline $\mathrm{RBO}$ & $860.4^{b}$ & $788.0^{\mathrm{b}}$ & $730.5^{\mathrm{a}}$ & $63.8^{c}$ & $152.9^{\mathrm{d}}$ & $40.9^{a}$ & $115.8^{b}$ \\
\hline FSO & $754.3^{c}$ & $678.9^{d}$ & $617.8^{\mathrm{d}}$ & $65.9^{b}$ & $158.2^{c}$ & $36.7^{c}$ & $99.1^{\mathrm{e}}$ \\
\hline SFO & $767.1^{\mathrm{c}}$ & $703.4^{c}$ & $645.8^{b c}$ & $63.3^{c}$ & $168.1^{b}$ & $35.2^{d}$ & $102.0^{\mathrm{d}}$ \\
\hline RPO & $753.9^{c}$ & $690.5^{\mathrm{cd}}$ & $635.3^{c}$ & $58.7^{\mathrm{d}}$ & $151.9^{\mathrm{d}}$ & $35.2^{d}$ & $107.7^{\mathrm{c}}$ \\
\hline \multicolumn{8}{|l|}{ Breed $^{c}$} \\
\hline AW & 793.5 & 726.5 & 678.8 & 64.3 & 170.6 & 35.7 & 106.5 \\
\hline $\mathrm{AW} \times \mathrm{EF}$ & 797.1 & 729.9 & 671.9 & 64.7 & 171.5 & 35.8 & 107.0 \\
\hline $\begin{array}{c}\text { SEM } \\
p \text {-values }\end{array}$ & 4.1 & 3.8 & 3.5 & 0.6 & 1.7 & 0.3 & 0.6 \\
\hline Treatment & 0.0001 & 0.0001 & 0.0001 & 0.0001 & 0.0001 & 0.0001 & 0.0001 \\
\hline Breed & 0.4483 & 0.4384 & 0.4423 & 0.3670 & 0.3492 & 0.5652 & 0.4358 \\
\hline $\mathrm{T} \times$ Breed & 0.7877 & 0.7982 & 0.7993 & 0.7557 & 0.6935 & 0.8934 & 0.8082 \\
\hline
\end{tabular}

${ }^{a}$ Dry matter intake (DMI), organic matter (OM), acid detergent fibre (ADF), neutral detergent fibre (NDF), ether extract (EE), crude protein (CP); ${ }^{b}$ Canola oil (CO), rice bran oil (RBO), flaxseed oil (FSO), safflower oil (SFO), rumen-protected oil (RPO); ${ }^{c}$ Awassi $(\mathrm{AW})$, East Friesian $(\mathrm{EF})$, Awassi $\times$ East Friesian $(\mathrm{AW} \times \mathrm{EF})$ crossbred. Values with different superscripts within columns are significantly different $(p<0.05)$.

Significant differences in dairy performance traits, milk composition, and body condition score were observed across treatments (Table 4). Ewes receiving RPO produced the greatest milk yield at $628 \mathrm{~g}$ /day, followed by SFO, RBO, CO, FSO, and the control ( $p<0.0001)$. Inconsistent with milk yield, fat concentration was highest in milk from the control $(p=0.015)$, whereas RBO yielded the greatest content of protein $(5.9 \mathrm{~g} / 100 \mathrm{~g})(p<0.0001)$, resulting in the highest concentration of solids-non-fat $(11.7 \mathrm{~g} / 100 \mathrm{~g})$ in this group. Although milk from ewes fed RPO had the least proportion of fat and protein at 6.6 and $5.4(\mathrm{~g} / 100 \mathrm{~g})$, respectively, this group produced the greatest fat yield (FY) (41 g/day; $p=0.0008$ ) and protein yield (34 g/day; $p=0.0004)$. There were no significant differences among treatments in the percentage of milk lactose. The type of oil included in the dietary supplement affected body conformation ( $p=0.0008$ ), although the mean BCS of experimental ewes only varied from 2.2-2.4 (Table 4). Since the cell counts for healthy sheep range from 10 to $200 \times 1000$ cells $/ \mathrm{mL}$, cell counts 
of all treatments ranged from 60 to $109 \times 1000$ cells $/ \mathrm{mL}$ (Table 4), indicating that all experimental animals were free from intramammary infections during the feeding trial.

Table 4. Effect of supplementation with diverse plant-derived oils on body condition score and lactation performance traits ${ }^{\text {a }}$.

\begin{tabular}{|c|c|c|c|c|c|c|c|c|c|c|}
\hline Item & MY & FCM & Fat & FY & Protein & PY & Lacto-se & SNF & SCC & BCS \\
\hline \multicolumn{11}{|c|}{ Treatment $^{\mathrm{b}}(\mathrm{T})$} \\
\hline Control & $484^{\mathrm{d}}$ & $542^{b c}$ & $7.4^{\mathrm{a}}$ & $36^{b c}$ & $5.4^{c}$ & $26^{c}$ & 4.9 & $10.9^{b c}$ & $109^{a}$ & $2.1^{\mathrm{c}}$ \\
\hline $\mathrm{CO}$ & $525^{\mathrm{c}}$ & $573^{b}$ & $7.2^{a b}$ & $38^{\mathrm{b}}$ & $5.5^{\mathrm{bc}}$ & $29^{b}$ & 4.9 & $11.1^{b c}$ & $98^{a b}$ & $2.3^{\mathrm{a}}$ \\
\hline RBO & $527^{c}$ & $578^{\mathrm{b}}$ & $7.2^{a b}$ & $38^{b}$ & $5.9^{\mathrm{a}}$ & $31^{b}$ & 4.9 & $11.7^{\mathrm{a}}$ & $73^{c}$ & $2.2^{b c}$ \\
\hline FSO & $489^{d}$ & $523^{c}$ & $6.9^{b c}$ & $34^{c}$ & $5.4^{c}$ & $26^{c}$ & 4.8 & $10.8^{c}$ & $60^{c}$ & $2.3^{\mathrm{a}}$ \\
\hline SFO & $562^{b}$ & $587^{b}$ & $6.6^{c}$ & $37^{b}$ & $5.6^{\mathrm{b}}$ & $31^{\mathrm{ab}}$ & 4.8 & $11.2^{b}$ & $105^{a b}$ & $2.2^{b c}$ \\
\hline RPO & $628^{a}$ & $649^{a}$ & $6.6^{c}$ & $41^{\mathrm{a}}$ & $5.4^{\mathrm{c}}$ & $34^{\mathrm{a}}$ & 4.8 & $11.0^{b c}$ & $81^{\mathrm{bc}}$ & $2.2^{b c}$ \\
\hline \multicolumn{11}{|l|}{ Breed $^{c}(B)$} \\
\hline $\mathrm{AW}$ & $496^{\mathrm{b}}$ & $535^{b}$ & 7.1 & $35^{b}$ & 5.5 & $27^{\mathrm{b}}$ & $4.8^{b}$ & 11.1 & $97^{\mathrm{a}}$ & $2.2^{b}$ \\
\hline $\mathrm{AW} \times \mathrm{EF}$ & $578^{a}$ & $617^{a}$ & 6.9 & $40^{\mathrm{a}}$ & 5.5 & $32^{\mathrm{a}}$ & $4.9^{\mathrm{a}}$ & 11.2 & $78^{b}$ & $2.3^{\mathrm{a}}$ \\
\hline SEM & 3.4 & 7.8 & 0.07 & 3.6 & 0.04 & 2.9 & 0.02 & 0.05 & 3.6 & 0.0 \\
\hline \multicolumn{11}{|l|}{$p$-Values } \\
\hline Treatment & 0.0001 & 0.0001 & 0.0001 & 0.0021 & 0.0001 & 0.0001 & 0.1689 & 0.0001 & 0.0002 & 0.0018 \\
\hline Breed (B) & 0.0001 & 0.0001 & 0.1765 & 0.0001 & 0.7444 & 0.0001 & 0.0006 & 0.1351 & 0.115 & 0.0030 \\
\hline Week (W) & 0.0001 & 0.0001 & 0.0001 & 0.0001 & 0.0001 & 0.0001 & 0.0001 & 0.0257 & 0.0012 & 0.0001 \\
\hline $\mathrm{T} \times \mathrm{B}$ & 0.0001 & 0.0001 & 0.0001 & 0.0002 & 0.0003 & 0.0001 & 0.0001 & 0.0257 & 0.0795 & 0.0002 \\
\hline $\mathrm{T} \times \mathrm{W}$ & 1.0000 & 1.0000 & 0.9766 & 0.9999 & 0.8717 & 1.0000 & 0.8348 & 0.8039 & 0.3630 & 0.9999 \\
\hline$B \times W$ & 0.9061 & 0.8724 & 0.9494 & 0.8517 & 0.9971 & 0.9380 & 0.6808 & 0.9910 & 0.9974 & 0.8640 \\
\hline
\end{tabular}

${ }^{a}$ Milk yield (MY, g/day), fat-corrected milk (FCM, g/day), fat (g/100 g milk), fat yield (FY, g/day), protein (g/100 g milk), protein yield (PY, g/day), lactose (g/100 g milk), solids-non-fat (SNF, g/100 g milk), somatic cell count $(\mathrm{SCC}, \times 1000$ cells $/ \mathrm{mL})$, body condition score (BCS); ${ }^{\mathrm{b}}$ Canola oil $(\mathrm{CO})$, rice bran oil (RBO), flaxseed oil (FSO), safflower oil (SFO), rumen-protected oil (RPO); ${ }^{\mathrm{c}}$ Awassi (AW), East Friesian (EF), Awassi $\times$ East Friesian $(\mathrm{AW} \times \mathrm{EF})$ crossbred. Values with different superscripts within columns are significantly different $(p<0.05)$.

It was evidenced that breed also had major impacts on milk production rather than milk composition (Table 4), with significantly higher milk $(p<0.0001)$, fat $(p<0.0001)$, and protein $(p<0.0001)$ yields observed in crossbred AW $\times$ EF than purebred AW. There were minor variations in terms of mean fat, protein, and lactose contents between $\mathrm{AW} \times \mathrm{EF}$ and $\mathrm{AW}$, despite the statistical difference in lactose percentage.

Weekly trends for BCS and lactation traits are presented in Figures 1 and 2. As observed in all treatment groups, BCS, fat percentage, and protein percentage (Figures $1 \mathrm{a}$ and $2 \mathrm{a}, \mathrm{b}$ ) increased, while milk yield decreased over the duration of the experimental period (Figure 1b). The best weekly milk yield trend was recorded in the RPO group, where its decrease was smaller ( 4.9 at the start to $3.9 \mathrm{~kg}$ /week) than the other groups at the end of the trial.

Figure 3 presents significant interactions between oil supplementation and breed in milk yield $(p<0.0001)$, fat percentage $(p<0.0001)$, and protein percentage $(p=0.0003)$. Regarding milk production, crossbred AW $\times$ EF ewes had greater responses to oil supplements than AW with the highest milk yield at $751 \mathrm{~g} /$ day observed in the RPO group (Figure 3a). Breed and diet interactions, however, were varied across treatments in which AW ewes fed with RBO produced the highest percentages of fat and protein (7.8 and $6.1 \mathrm{~g} / 100 \mathrm{~g}$, respectively). 
(a)

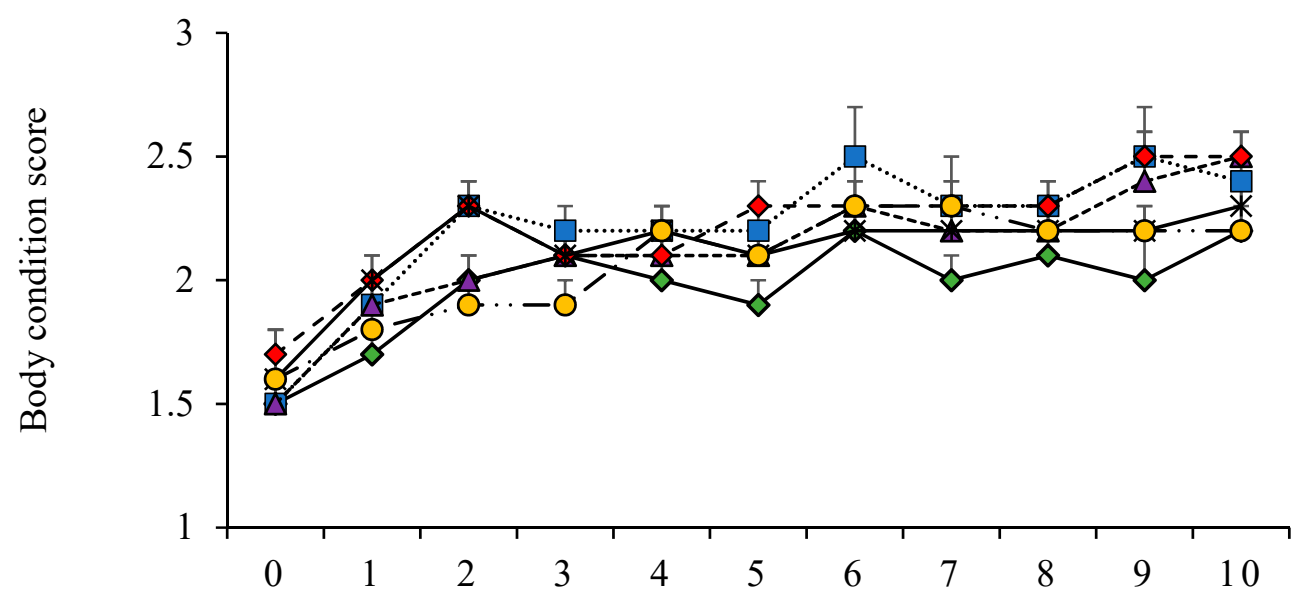

(b)

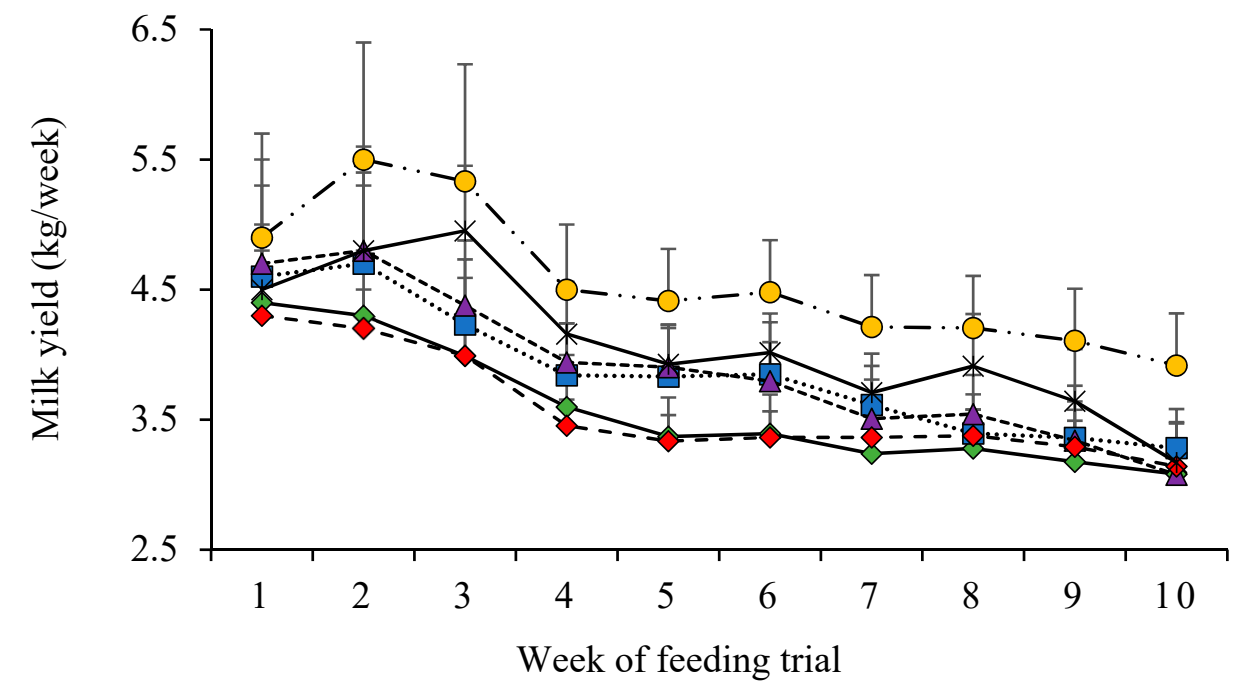

$\prec$ Control $\cdots \square \square \cdot \cdots \mathrm{CO}----\cdot$ RBO $-\prec-$ FSO $\rightarrow$ SFO - O-RPO

Figure 1. Weekly trends in body condition score (a) and milk yield (b). Canola oil (CO), rice bran oil (RBO), flaxseed oil (FSO), safflower oil (SFO), rumen-protected oil (RPO). 


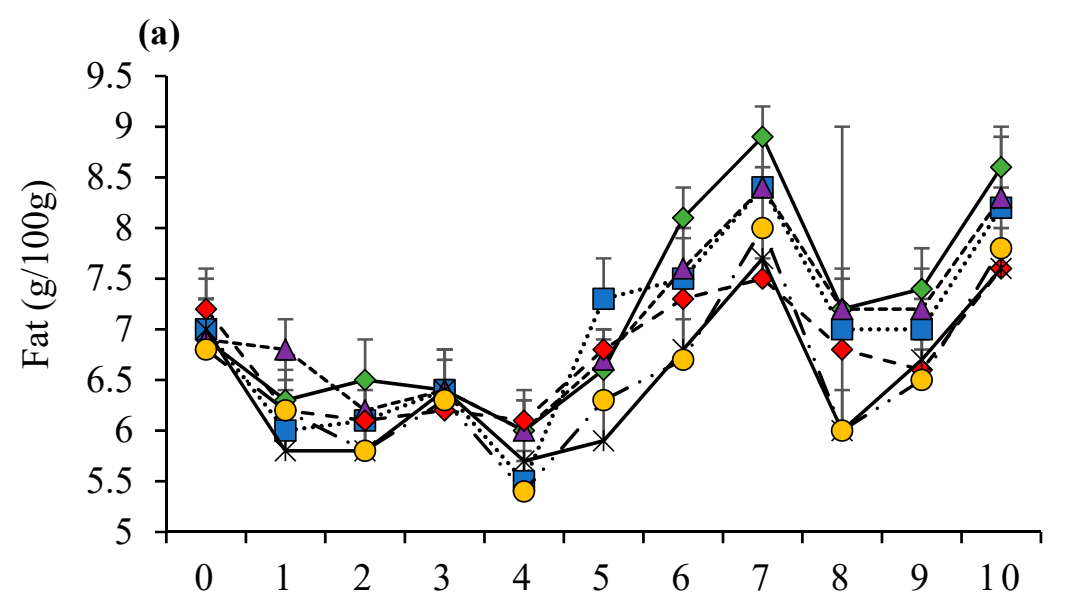

(b)

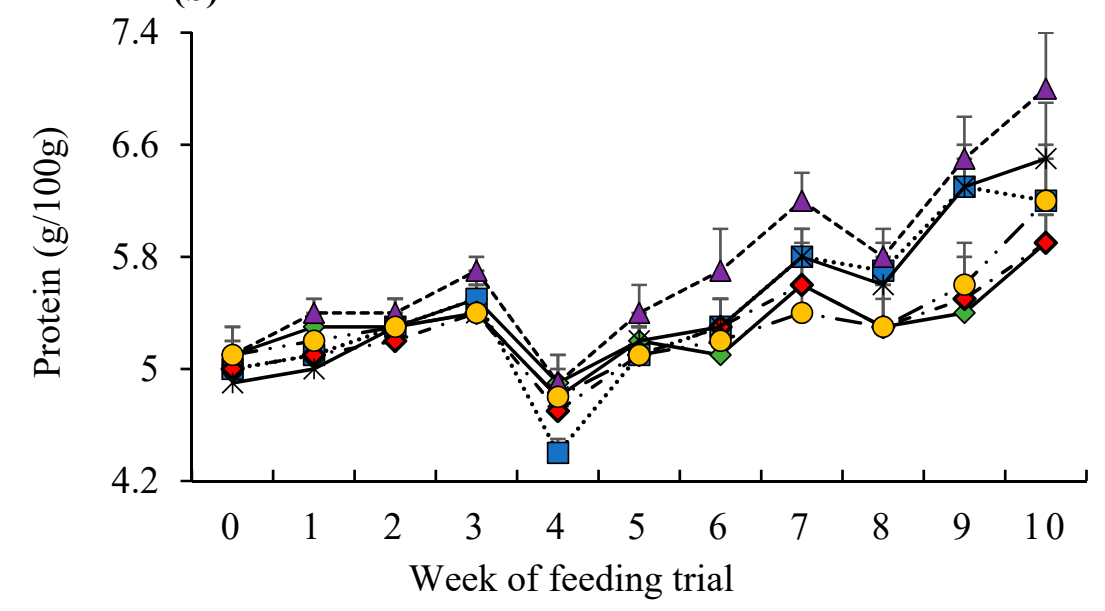

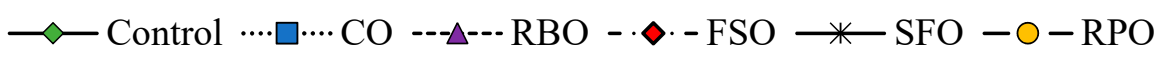

Figure 2. Weekly trends in milk fat (a) and milk protein (b) concentration. Canola oil (CO), rice bran oil (RBO), flaxseed oil (FSO), safflower oil (SFO), rumen-protected oil (RPO). 
(a)

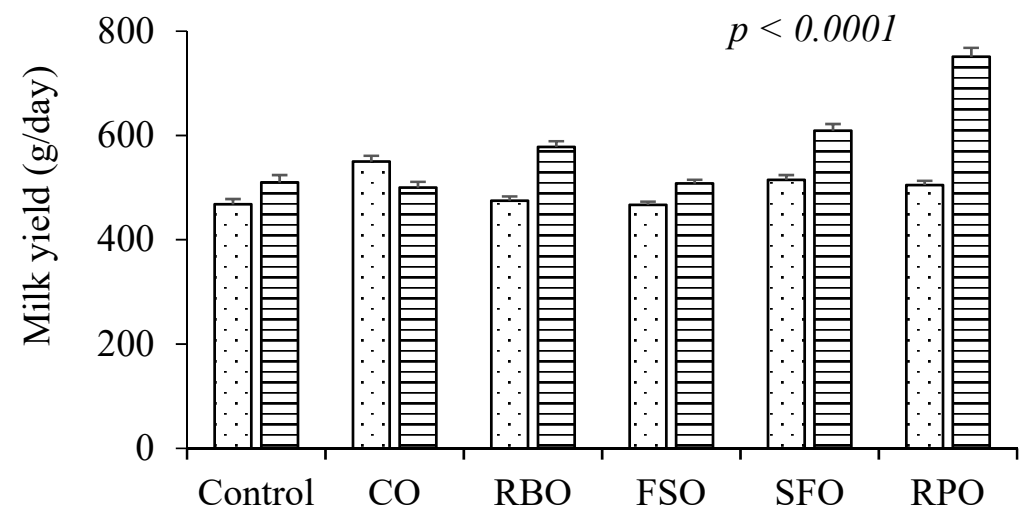

(b)

$p<0.0001$

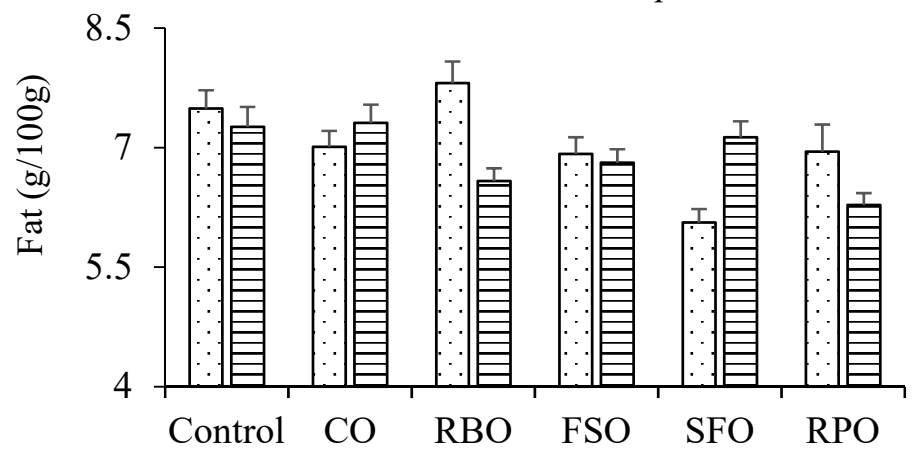

(c)

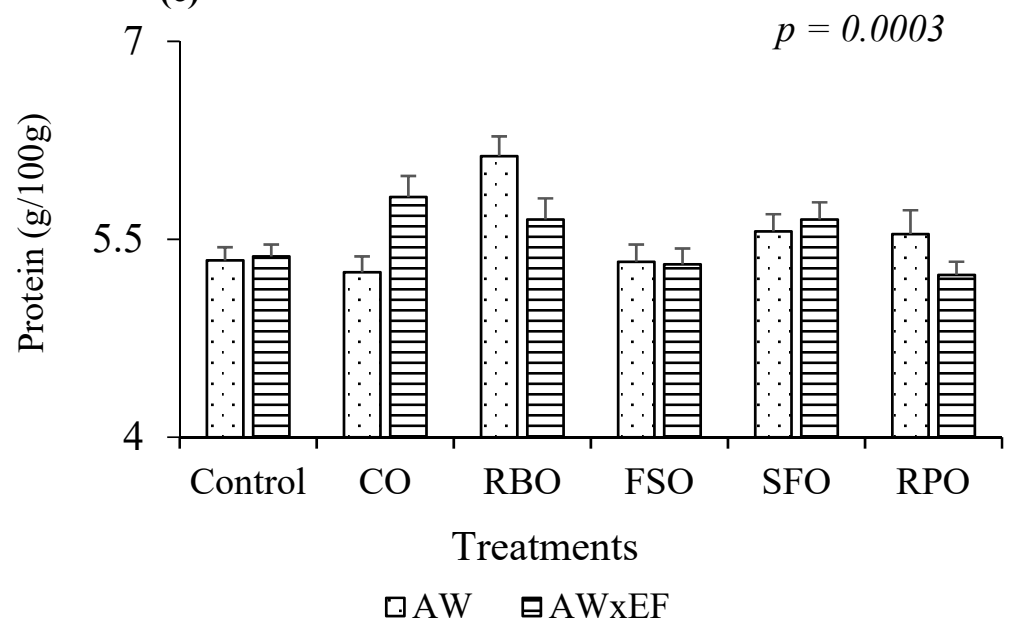

Figure 3. Supplementary diet and breed interactions on (a) milk yield; (b) milk fat; and (c) milk protein. Canola oil (CO), rice bran oil (RBO), flaxseed oil (FSO), safflower oil (SFO), rumen-protected oil (RPO). 


\section{Discussion}

\subsection{Effect of Dietary Supplements on Dry Matter Intake and Body Condition Score}

The decrease in DMI was inconsistent with previous studies that examined the effect of adding $2 \%$ plant oil in the diets of dairy ewes [33], but was similar to recent reports in dairy cows that found a negative impact of a high level of supplemented oil on DMI [24,34-36]. According to Illius et al. [37], voluntary ruminant feed intake is affected by nutrient and energy flows related to ruminal fermentation. Adding high levels of oil in diets that was the case of the current study, may reduce diet acceptability [38], which is caused by ruminal function reduction. Other studies have shown that oil addition to diets reduces fibre digestibility, DMI, and feed palatability in ruminants, suggesting negative effects of plant oils on animals' appetite. This occurs due to selection against microorganisms with cellulolytic capability, leading to a decrease in ruminal fibre digestion [39]. Moreover, DMI differences among oil supplement groups (with the highest observed in RBO) indicates the effect of oil type on nutrient digestibility [40].

Known as an important indicator of cow health status in dairy management, body condition score (BCS) is also regularly used to estimate fatness in the form of energy reserves as well as animal welfare status [41-44]. A meta-analysis by Kenyon et al. [29] demonstrated a positive association between BCS at breeding and ewe reproductive traits (pregnancy rate and number of lambs born). Generally, these parameters increase as BCS increases from 2.0 to 3.0 [45-47]. At the commencement of the feeding trial, the average BCS of the experimental animals was 1.5; a reflection of the low quality pastures the ewes were grazing and a pointer to fat mobilisation from body reserves for sustaining milk synthesis [48]. At the end of the feeding trial, average BCS values of ewes fed CO, RBO, and FSO rose to $2.55,2.60$, and 2.55, respectively. These BCS were within the target of 2.5-3.0 [29], which suggests that the use of such supplements could have a positive effect on not only milk yield, but also reproductive performance and the general welfare of dairy ewes.

\subsection{Effect of Dietary Supplements on Milk Yield and Milk Composition}

Despite the wide accessibility and availability of canola and rice bran in Australia [49,50], the extent of use of these plant lipid sources as dietary supplements in the Australian dairy industry is unknown. Supplementing diets with canola and rice bran oils in the current study increased milk yield without exerting negative effects on milk fat and protein compositions. Lunsin et al. [24] supplemented dairy cow diets with $2 \%, 4 \%$, and $6 \%$ rice bran oil in a confined system and did not observe any statistical variation in milk production. This was inconsistent with a reduction in the milk yield of dairy goats fed total mixed rations that included $5 \%, 10 \%$, and $20 \%$ rice bran [25]. In contrast, an increase in the milk yield of the RBO group observed in the current study suggests the advanced effect of rice bran oil inclusion in a pasture-based system compared to a confined system. Regarding milk fat and protein concentrations, supplementation of grazing dairy ewes with rice bran oil in the current study, had no influence on milk fat. However, it significantly enhanced milk protein even though the potential to alter milk protein concentration by changing the dietary composition is considered less compared with the potential to alter milk fat composition [9]. This increment of change in protein composition in milk agrees with the findings of Park et al. [25] in goat milk, but disagrees with a decrease observed in cows when the percentage of dietary RBO was increased [24]. On the other hand, supplementation of ewes in this study and cows [19] in similar pasture-based dairy systems with $5 \%$ of CO demonstrated an increase in milk yield. However, while inclusion of CO had no statistically significant effect on all milk components of lactating ewes, Otto et al. [19] reported marginal decreases in fat and protein percentages of cow milk. These contrasting results in response to rice bran and canola oil supplementation suggest that there could be physiological differences between species in lipid metabolisms that might need further investigation.

Variations in results assessing the effect of mostly whole or extruded flaxseed [51] and flaxseed oil [52] on milk production and composition of dairy ewes have been reported. Akin to the current 
results, no statistical difference in milk production was observed when ewes were supplemented with extruded linseed at $128 \mathrm{~g} /$ day [53] and $220 \mathrm{~g} /$ day [54] or linseed oil at $6 \%$ of the estimated total DM intake [52]. These findings were in contrast with other authors who distinguished either an increase [27] or a decrease [28] in milk yield of dairy ewes fed $250 \mathrm{~g} /$ day of whole flaxseed or $200 \mathrm{~g} /$ day of extruded flaxseed, respectively. Milk fat depression in response to supplementation with FSO in this study was supported by other studies in sheep [53] and cows [34,55,56], but disagrees with others that showed no changes in sheep $[27,52,54]$ or a minor increase in sheep $[26,28]$ and goats [57]. These variations might be due to the multi nutritional effects, including energy balance, NDF concentration, and feed particle size, that have strong correlations with milk yield and milk fat concentration [11].

Safflower, which is grown in over 60 countries [58], has been used widely as a supplement in ruminant diets [59]. Despite studies investigating the effects of using various types of safflower on bovine and caprine performance [60], there is relatively little information on its effectiveness as a supplement for influencing milk yield and composition in lactating ewes. In this study, supplementation of grazing dairy ewes with SFO increased milk production by $16 \%$. This supports the findings of Ahmadpour et al. [61], who supplemented dairy cows with rolled safflower seed at $3 \%$ and $6 \%$ and reported increases in milk yield by $2 \%$ and $9 \%$, respectively. Other studies have, however, reported no significant effects on milk yield when the diets of lactating cows $[23,59,62,63]$ and goats [64] were supplemented with safflower oil or seed. Similarly, variable responses and changes in milk components were observed when the diets of lactating goats or cows were supplemented with safflower. Some results portrayed negative effects [23,34,64], which align with our results, while others did not observe any significant effects [59,61-63]. The wide range of inclusion rates and variation in dietary components in these studies might have led to the variable responses reported.

An outstanding enhancement of milk yield by approximately $30 \%$ compared to the control animals was observed in ewes supplemented with RPO. Increases in fat $(13 \%)$ and protein $(31 \%)$ were also observed. These incremental improvements in milk yield and total solids production play an important role in positively enhancing the economic benefits for dairy sheep producers as most sheep milk is used for cheese making [65]. The quantity of cheese that can be produced from sheep milk is limited by the concentrations of fat and, especially, protein in raw milk [11]. Reviews on bypass fat supplementation studies suggest a consistent increase in the milk production of lactating cows by $5.5 \%-24 \%$ [66], while variable responses were presented in lactating ewes [11]. According to Pulina et al. [11], positive effects of supplementing rumen-protected fat on dairy sheep production performance generally occur with feeding trials longer than 4 weeks. This was confirmed in the current work, while short-term studies had a minor reduction or no change [67-69]. In this study, we recorded a reduction in the concentration of milk fat in the RPO group. This agrees with the findings of Rotunno et al. [70], who fed ewes with $4 \%$ and $8 \%$ rumen-protected fat, whereas this disagreed with the consistent increase in milk fat concentration reported by Pulina et al. [11]. Differences in dietary components, type and dosage of protected fat, feeding regimes, or stage of lactation might have accounted for this contrasting set of outcomes.

\subsection{Effect of Breed on Animal Performance}

The East Friesian (EF) breed of sheep was developed in northern Germany and the Netherlands, and has become one of the world's most productive dairy sheep. The EF has earned the reputation as the most productive dairy sheep breed in terms of milk yield [71]. However, it has a low ability to adapt under unfavourable environmental conditions, especially excessive heat and humidity [72]. Thus, this breed has been used widely in crossbreeding systems to improve milk production of local breeds in various temperate environments [72-74]. Together with Awassi (AW), the predominant breed in the Eastern Mediterranean countries [75], EF was introduced to Australia in the 1990s, and since, has been used more widely in the dairy sheep industry as reported by the Australian Rural Industries Research and Development Corporation [76]. The improvement in milk yield without any negative effects on 
the relative content of milk composition in crossbred ewes $\mathrm{AW} \times \mathrm{EF}$ was akin to Clement et al. [77], whereas it was inconsistent with Gootwine and Goot [72], who demonstrated similar milk volumes between AW and AW $\times$ EF. Local heat stress that leads to a depression of feed intake, milk production, and reproduction $[78,79]$ might be the principal factor for this performance variation by crossbreds in some studies. Moreover, statistically significant variation in the interaction between treatments and sire breed regarding milk production and composition, but not feed intake, in the current research suggests that gene regulation may be involved in experimental oil metabolism. Therefore, identification of regulated genes for milk yield and composition in response to plant and rumen-protected marine oil supplements needs to be investigated.

\section{Conclusions}

The current study demonstrated that canola, rice bran, safflower, and rumen-protected EPA + DHA could improve lactation traits without any negative impact on BCS of dairy ewes grazing low quality pasture. Under the same nutrition and management conditions, crossbred $\mathrm{AW} \times \mathrm{EF}$ significantly showed greater lactation performance than AW. Utilising these oil supplements combined with crossbreeding the AW and EF sheep breeds is, therefore, recommended for Australian sheep milk producers utilising pasture-based systems. In addition, the novel potential of supplementing dairy sheep with rice bran and canola oils explored in this study may need further research to better elucidate their metabolic mechanisms.

Author Contributions: Conceptualization, A.E.O.M-A; methodology, A.E.O.M-A, P.D.N., B.S.M-A, Q.V.N., H.V.L., D.V.N.; J.R.O.; P.N.; software, A.E.O.M-A; validation, A.E.O.M-A, P.D.N. and B.S.M-A.; formal analysis, Q.V.N., investigation, Q.V.N., resources, A.E.O.M-A.; data curation, writing-original draft preparation, Q.V.N.; writing-review and editing, A.E.O.M-A, P.D.N. and B.S.M-A.; supervision, A.E.O.M-A, P.D.N. and B.S.M-A.; project administration, A.E.O.M-A; funding acquisition, A.E.O.M-A.

Funding: This research was funded by Australian Awards PhD Scholarship from the Australian Government's Department of Foreign Affairs and Trade awarded to the first-named author and the APC was funded by the College of Public Health, Medical and Veterinary Sciences, James Cook University, Queensland, Australia.

Acknowledgments: In addition to the funding body, we acknowledge CopRice Feeds, Cobden, Victoria, Australia, for producing the experimental pellets to specification. We thank Diane Rae, Nicole Gilliver, Ryan Hartshorn and all staff of Grandvewe Cheeses Farm, Birchs Bay, Woodbridge, Tasmania, Australia, for supplying experimental animals, milking and other facilities for this research project. John Cavalieri is gratefully acknowledged for his valuable editorial input.

Conflicts of Interest: The authors declare no conflict of interest. The funders had no role in the design of the study; collection, analyses, or interpretation of data; in the writing of the manuscript, or in the decision to publish the results.

\section{References}

1. Park, Y.W.; Juarez, M.; Ramos, M.; Haenlein, G.F.W. Physico-chemical characteristics of goat and sheep milk. Small Rumin. Res. 2007, 68, 88-113. [CrossRef]

2. Silanikove, N.; Leitner, G.; Merin, U. The interrelationships between lactose intolerance and the modern dairy industry: Global perspectives in evolutional and historical backgrounds. Nutrients 2015, 7, 7312-7331. [CrossRef] [PubMed]

3. AgriFutures Australia. Dairy Sheep. 2013. Available online: https://www.agrifutures.com.au/farmdiversity/dairy-sheep/ (accessed on 31 April 2018).

4. Dairy Australia. Milk. 2018. Available online: https://www.dairyaustralia.com.au/industry/productionand-sales/milk (accessed on 31 April 2018).

5. Abd Allah, M.; Abass, S.; Allam, F.M. Factors affecting the milk yield and composition of Rahmani and Chios sheep. Int. J. Livest. Prod. 2011, 2, 24-30.

6. Ayadi, M.; Matar, A.; Aljumaah, R.; Alshaikh, M.; Abouheif, M. Factors affecting milk yield, composition and udder health of Najdi ewes. Int. J. Anim. Vet. Adv. 2014, 6, 28-33.

7. Caja, G.; Bocquier, F. Effects of nutrition on the composition of sheep's milk. Cah. Opt. Mediterr. 2000, $55,59-74$. 
8. Hristov, A.N.; Price, W.J.; Shafii, B. A meta-analysis examining the relationship among dietary factors, dry matter intake, and milk and milk protein yield in dairy cows. J. Dairy Sci. 2004, 87, 2184-2196. [CrossRef]

9. Kennelly, J.J.; Bell, J.A.; Keating, A.F.; Doepel, L. Nutrition as a tool to alter milk composition. Adv. Dairy Technol. 2005, 17, 255-275.

10. Chilliard, Y.; Ferlay, A.; Rouel, J.; Lamberet, G. A review of nutritional and physiological factors affecting goat milk lipid synthesis and lipolysis. Livest. Prod. Sci. 2003, 86, 1751-1770. [CrossRef]

11. Pulina, G.; Nudda, A.; Battacone, G.; Cannas, A. Effects of nutrition on the contents of fat, protein, somatic cells, aromatic compounds, and undesirable substances in sheep milk. Anim. Feed Sci. Technol. 2006, 131, 255-291. [CrossRef]

12. McGuire, M.A.; McGuire, M.K. Conjugated linoleic acid (CLA): A ruminant fatty acid with beneficial effects on human health. J. Anim. Sci. 2000, 77, 1-8. [CrossRef]

13. Calder, P.C. Long-chain fatty acids and inflammation. Proc. Nutr. Soc. 2012, 71, 284-289. [CrossRef]

14. Calder, P.C. Omega-3 polyunsaturated fatty acids and inflammatory processes: Nutrition or pharmacology? Br. J. Clin. Pharmacol. 2013, 75, 645-662. [CrossRef]

15. Belury, M.A. Inhibition of carcinogenesis by conjugated linoleic acid: Potential mechanisms of action. J. Nutr. 2002, 132, 2995-2998. [CrossRef] [PubMed]

16. Calon, F.; Cole, G. Neuroprotective action of omega-3 polyunsaturated fatty acids against neurodegenerative diseases: Evidence from animal studies. Prostag. Leukotr. Ess. 2007, 77, 287-293. [CrossRef] [PubMed]

17. Bernal-Santos, G.; O’Donnell, A.M.; Vicini, J.L.; Hartnell, G.F.; Bauman, D.E. Hot topic: Enhancing omega-3 fatty acids in milk fat of dairy cows by using stearidonic acid-enriched soybean oil from genetically modified soybeans. J. Dairy Sci. 2010, 93, 32-37. [CrossRef] [PubMed]

18. Castro, T.; Manso, T.; Jimeno, V.; Del Alamo, M.; Mantecon, A.R. Effects of dietary sources of vegetable fats on performance of dairy ewes and conjugated linoleic acid (CLA) in milk. Small Rumin. Res. 2009, 84, 47-53. [CrossRef]

19. Otto, J.R.; Nish, P.; Balogun, R.O.; Freeman, M.J.; Malau-Aduli, B.S.; Lane, P.A.; Malau-Aduli, A.E.O. Effect of dietary supplementation of pasture-based primiparous Holstein-Friesian cows with degummed crude canola oil on body condition score, liveweight, milk yield and composition. J. Appl. Anim. Res. 2016, 44, $194-200$. [CrossRef]

20. Pirondini, M.; Colombini, S.; Mele, M.; Malagutti, L.; Rapetti, L.; Galassi, G.; Crovetto, G.M. Effect of dietary starch concentration and fish oil supplementation on milk yield and composition, diet digestibility, and methane emissions in lactating dairy cows. J. Dairy Sci. 2015, 98, 357-372. [CrossRef]

21. Pulina, G.; Macciotta, N.; Nudda, A. Milk composition and feeding in the Italian dairy sheep. Ital. J. Anim. Sci. 2005, 4, 5-14. [CrossRef]

22. Akbaridoust, G.; Plozza, T.; Trenerry, V.C.; Wales, W.J.; Auldist, M.J.; Dunshea, F.R.; Ajlouni, S. Influence of different systems for feeding supplements to grazing dairy cows on milk fatty acid composition. J. Dairy Res. 2014, 81, 156-163. [CrossRef]

23. Bell, J.A.; Griinari, J.M.; Kennelly, J.J. Effect of safflower oil, flaxseed oil, monensin, and vitamin E on concentration of conjugated linoleic acid in bovine milk fat. J. Dairy Sci. 2006, 89, 733-748. [CrossRef]

24. Lunsin, R.; Wanapat, M.; Rowlinson, P. Effect of cassava hay and rice bran oil supplementation on rumen fermentation, milk yield and milk composition in lactating dairy cows. Asian-Australas J. Anim. Sci. 2012, 25, 1364-1373. [CrossRef] [PubMed]

25. Park, J.K.; Kwon, E.G.; Kim, C.H. Effects of increasing supplementation levels of rice bran on milk production and fatty acid composition of milk in Saanen dairy goats. Anim. Prod. Sci. 2013, 53, 413-418. [CrossRef]

26. Caroprese, M.; Albenzio, M.; Bruno, A.; Fedele, V.; Santillo, A.; Sevi, A. Effect of solar radiation and flaxseed supplementation on milk production and fatty acid profile of lactating ewes under high ambient temperature. J. Dairy Sci. 2011, 94, 3856-3867. [CrossRef] [PubMed]

27. Caroprese, M.; Ciliberti, M.G.; Marino, R.; Santillo, A.; Sevi, A.; Albenzio, M. Polyunsaturated fatty acid supplementation: Effects of seaweed Ascophyllum nodosum and flaxseed on milk production and fatty acid profile of lactating ewes during summer. J. Dairy Res. 2016, 83, 289-297. [CrossRef]

28. Mughetti, L.; Sinesio, F.; Acuti, G.; Antonini, C.; Moneta, E.; Peparaio, M.; Trabalza-Marinucci, M. Integration of extruded linseed into dairy sheep diets: Effects on milk composition and quality and sensorial properties of Pecorino cheese. Anim. Feed Sci. Technol. 2012, 178, 27-39. [CrossRef] 
29. Kenyon, P.R.; Maloney, S.K.; Blache, D. Review of sheep body condition score in relation to production characteristics. N. Z. J. Agric. Res. 2014, 57, 38-64. [CrossRef]

30. Association of Official Analytical Chemists (AOAC). Official Methods of Analysis, 15th ed.; AOAC: Washington, DC, USA, 1990.

31. Mavrogenis, A.P.; Papachristoforou, C. Estimation of the energy value of milk and prediction of fat-corrected milk yield in sheep. Small Rumin. Res. 1988, 1, 229-236. [CrossRef]

32. SAS. Statistical Analysis System, Version 9.2; SAS Institute: Cary, NC, USA, 2009.

33. Hervas, G.; Luna, P.; Mantecon, A.R.; Castanares, N.; de la Fuente, M.A.; Juarez, M.; Frutos, P. Effect of diet supplementation with sunflower oil on milk production, fatty acid profile and ruminal fermentation in lactating dairy ewes. J. Dairy Res. 2008, 75, 399-405. [CrossRef]

34. Ammah, A.A.; Benchaar, C.; Bissonnette, N.; Gevry, N.; Ibeagha-Awemu, E.M. Treatment and post-treatment effects of dietary supplementation with safflower oil and linseed oil on milk components and blood metabolites of Canadian Holstein cows. J. Appl. Anim. Res. 2018, 46, 898-906. [CrossRef]

35. Mapato, C.; Wanapat, M.; Cherdthong, A. Effects of urea treatment of straw and dietary level of vegetable oil on lactating dairy cows. Trop. Anim. Health Prod. 2010, 42, 1635-1642. [CrossRef] [PubMed]

36. Shingfield, K.J.; Reynolds, C.K.; Hervas, G.; Griinari, J.M.; Grandison, A.S.; Beever, D.E. Examination of the persistency of milk fatty acid composition responses to fish oil and sunflower oil in the diet of dairy cows. J. Dairy Sci. 2006, 89, 714-732. [CrossRef]

37. Illius, A.W.; Jessop, N.S. Metabolic constraints on voluntary intake in ruminants. J. Anim. Sci. 1996, 74, 3052-3062. [CrossRef]

38. Petit, H.V.; Ivan, M.; Mir, P.S. Effects of flaxseed on protein requirements and N excretion of dairy cows fed diets with two protein concentrations. J. Dairy Sci. 2005, 88, 1755-1764. [CrossRef]

39. Gonthier, C.; Mustafa, A.F.; Berthiaume, R.; Petit, H.V.; Martineau, R.; Ouellet, D.R. Effects of feeding micronized and extruded flaxseed on ruminal fermentation and nutrient utilization by dairy cows. J. Dairy Sci. 2004, 87, 1854-1863. [CrossRef]

40. Doreau, M.; Chilliard, Y. Digestion and metabolism of dietary fat in farm animals. Br. J. Nutr. 1997, 78, S15-S35. [CrossRef] [PubMed]

41. Malau-Aduli, A.E.O.; Anlade, Y.R. Comparative study of milk compositions of cattle, sheep and goats in Nigeria. Anim. Sci. J. 2002, 73, 541-544. [CrossRef]

42. Morgan-Davies, C.; Waterhouse, A.; Pollock, M.L.; Milner, J.M. Body condition score as an indicator of ewe survival under extensive conditions. Anim. Welfare 2008, 17, 71-77.

43. Phythian, C.J.; Michalopoulou, E.; Jones, P.H.; Winter, A.C.; Clarkson, M.J.; Stubbings, L.A.; Grove-White, D.; Cripps, P.J.; Duncan, J.S. Validating indicators of sheep welfare through a consensus of expert opinion. Animal 2011, 5, 943-952. [CrossRef]

44. Roche, J.R.; Friggens, N.C.; Kay, J.K.; Fisher, M.W.; Stafford, K.J.; Berry, D.P. Invited review: Body condition score and its association with dairy cow productivity, health, and welfare. J. Dairy Sci. 2009, 92, 5769-5801. [CrossRef]

45. Abdel-Mageed, I. Body condition scoring of local Ossimi ewes at mating and its impact on fertility and prolificacy. Egypt. J. Sheep Goat Sci. 2009, 4, 37-44.

46. Kenyon, P.R.; Morel, P.C.H.; Morris, S.T. The effect of individual liveweight and condition scores of ewes at mating on reproductive and scanning performance. N. Zeal. Vet. J. 2004, 52, 230-235. [CrossRef]

47. Yilmaz, M.; Altin, T.; Karaca, O.; Cemal, I.; Bardakcioglu, H.E.; Yilmaz, O.; Taskin, T. Effect of body condition score at mating on the reproductive performance of Kivircik sheep under an extensive production system. Trop. Anim. Health Prod. 2011, 43, 1555-1560. [CrossRef]

48. Komaragiri, M.V.S.; Casper, D.P.; Erdman, R.A. Factors affecting body tissue mobilization in early lactation dairy cows. 2. Effect of dietary fat on mobilization of body fat and protein. J. Dairy Sci. 1998, 81, 169-175. [CrossRef]

49. Ricegrowers' Association of Australia (RAG). Overview of the Australian Rice Industry. 2013. Available online: http:/ / www.rga.org.au/f.ashx/overview.pdf (accessed on 18 December 2018).

50. Seymour, M.; Kirkegaard, J.A.; Peoples, M.B.; White, P.F.; French, R.J. Break-crop benefits to wheat in Western Australia-Insights from over three decades of research. Crop Pasture Sci. 2012, 63, 1-16. [CrossRef] 
51. Nudda, A.; Battacone, G.; Neto, O.B.; Cannas, A.; Francesconi, A.H.D.; Atzori, A.S.; Pulina, G. Feeding strategies to design the fatty acid profile of sheep milk and cheese. R. Bras. Zootec. 2014, 43, 445-456. [CrossRef]

52. Antonacci, L.E.; Bussetti, M.; Rodriguez, M.A.; Cano, A.V.; Gagliostro, G.A. Effect of diet supplementation with combinations of soybean and linseed oils on milk production and fatty acid profile in lactating dairy ewes. Agric. Sci. 2018, 9, 200-220.

53. Gomez-Cortes, P.; Gallardo, B.; Mantecon, A.R.; Juarez, M.; de la Fuente, M.A.; Manso, T. Effects of different sources of fat (calcium soap of palm oil vs. extruded linseed) in lactating ewes' diet on the fatty acid profile of their suckling lambs. Meat Sci. 2014, 96, 1304-1312. [CrossRef]

54. Nudda, A.; Correddu, F.; Marzano, A.; Battacone, G.; Nicolussi, P.; Bonelli, P.; Pulina, G. Effects of diets containing grape seed, linseed, or both on milk production traits, liver and kidney activities, and immunity of lactating dairy ewes. J. Dairy Sci. 2015, 98, 1157-1166. [CrossRef] [PubMed]

55. Brossillon, V.; Reis, S.F.; Moura, D.C.; Galvao, J.G.B.; Oliveira, A.S.; Cortes, C.; Brito, A.F. Production, milk and plasma fatty acid profile, and nutrient utilization in Jersey cows fed flaxseed oil and corn grain with different particle size. J. Dairy Sci. 2018, 101, 2127-2143. [CrossRef] [PubMed]

56. Li, R.; Beaudoin, F.; Ammah, A.A.; Bissonnette, N.; Benchaar, C.; Zhao, X.; Lei, C.Z.; Ibeagha-Awemu, E.M. Deep sequencing shows microRNA involvement in bovine mammary gland adaptation to diets supplemented with linseed oil or safflower oil. BMC Genomics 2015, 16, 884. [CrossRef] [PubMed]

57. Nudda, A.; Battacone, G.; Atzori, A.S.; Dimauro, C.; Rassu, S.P.G.; Nicolussi, P.; Bonelli, P.; Pulina, G. Effect of extruded linseed supplementation on blood metabolic profile and milk performance of Saanen goats. Animal 2013, 7, 1464-1471. [CrossRef] [PubMed]

58. Glibert, J.S.; Porter, T. International Safflower Production-An Overview. In Proceedings of the 7th International Safflower Conference, Wagga Wagga, NSW, Australia, 3-6 November 2008; pp. 1-7.

59. Alizadeh, A.R.; Alikhani, M.; Ghorbani, G.R.; Rahmani, H.R.; Rashidi, L.; Loor, J.J. Effects of feeding roasted safflower seeds (variety IL-111) and fish oil on dry matter intake, performance and milk fatty acid profiles in dairy cattle. J. Anim. Physiol. Anim. Nutr. 2012, 96, 466-473. [CrossRef] [PubMed]

60. Shingfield, K.J.; Bonnet, M.; Scollan, N.D. Recent developments in altering the fatty acid composition of ruminant-derived foods. Animal 2013, 7, 132-162. [CrossRef]

61. Ahmadpour, A.; Aliarabi, H.; Khan, M.G.; Patton, R.A.; Bruckmaier, R.M. Temporal changes in milk fatty acid distribution due to feeding different levels of rolled safflower seeds to lactating Holstein cows. J. Dairy Sci. 2017, 100, 4484-4499. [CrossRef] [PubMed]

62. Dschaak, C.M.; Noviandi, C.T.; Eun, J.S.; Fellner, V.; Young, A.J.; ZoBell, D.R.; Israelsen, C.E. Ruminal fermentation, milk fatty acid profiles, and productive performance of Holstein dairy cows fed 2 different safflower seeds. J. Dairy Sci. 2011, 94, 5138-5150. [CrossRef] [PubMed]

63. Oguz, M.N.; Oguz, F.K.; Buyukoglu, T.I. Effect of different concentrations of dietary safflower seed on milk yield and some rumen and blood parameters at the end stage of lactation in dairy cows. R. Bras. Zootec. 2014, 43, 207-211. [CrossRef]

64. Shi, H.P.; Luo, J.; Zhang, W.; Sheng, H.J. Using safflower supplementation to improve the fatty acid profile in milk of dairy goat. Small Rumin. Res. 2015, 127, 68-73. [CrossRef]

65. Balthazar, C.F.; Pimentel, T.C.; Ferrão, L.L.; Almada, C.N.; Santillo, A.; Albenzio, M.; Mollakhalili, N.; Mortazavian, A.M.; Nascimento, J.S.; Silva, M.C.; et al. Sheep Milk: Physicochemical Characteristics and Relevance for Functional Food Development. Compr. Rev. Food Sci. Food Saf. 2017, 16, 247-262. [CrossRef]

66. Naik, P.K. Bypass Fat in Dairy Ration-A Review. Anim. Nutr. Feed Technol. 2013, 13, 147-163.

67. Appeddu, L.A.; Ely, D.G.; Aaron, D.K.; Deweese, W.P.; Fink, E. Effects of supplementing with calcium salts of palm oil fatty acids or hydrogenated tallow on ewe milk production and twin lamb growth. J. Anim. Sci. 2004, 82, 2780-2789. [CrossRef] [PubMed]

68. Garcia, C.D.; Hernandez, M.P.; Cantalapiedra, G.; Salas, J.M.; Merino, J.A. Bypassing the rumen in dairy ewes: The reticular groove reflex vs. calcium soap of olive fatty acids. J. Dairy Sci. 2005, 88, 741-747. [CrossRef]

69. Kitessa, S.M.; Peake, D.; Bencini, R.; Williams, A.J. Fish oil metabolism in ruminants. Anim. Feed Sci. Technol. 2003, 108, 1-14. [CrossRef]

70. Rotunno, T.; Sevi, A.; Di Caterina, R.; Muscio, A. Effects of graded levels of dietary rumen-protected fat on milk characteristics of Comisana ewes. Small Rumin. Res. 1998, 30, 137-145. [CrossRef] 
71. Haenlein, G.F.W. About the evolution of goat and sheep milk production. Small Rumin. Res. 2007, 68, 3-6. [CrossRef]

72. Gootwine, E.; Goot, H. Lamb and milk production of Awassi and East-Friesian sheep and their crosses under Mediterranean environment. Small Rumin. Res. 1996, 20, 255-260. [CrossRef]

73. Konečná, L.; Kuchtík, J.; Králíčková, Š.; Pokorná, M.; Šustová, K.; Filipčík, R.; Lužová, T. Effect of different crossbreeds of Lacaune and East Friesian breeds on milk yield and basic milk parameters. Acta Univ. Agric. Silvic. Meldel. Brun. 2013, 61,93-98. [CrossRef]

74. Thomas, D.L.; Berger, Y.M.; McKusick, B.C. Milk and lamb production of East Friesian-cross ewes in northwestern Wisconsin. In Proceedings of the 4th Great Lakes Dairy Sheep Symposium, Spooner, WI, USA, 25-27 June 1998; pp. 11-17.

75. Galal, S.; Gursoy, O.; Shaat, I. Awassi sheep as a genetic resource and efforts for their genetic improvement-A review. Small Rumin. Res. 2008, 79, 99-108. [CrossRef]

76. Stubbs, A.; Abud, G.; Bencini, R. Dairy Sheep Manual: Farm Management Guidelines; Rural Industries research and Development Corporation: Wagga Wagga, NSW, Australia, 2009.

77. Clement, P.; Agboola, S.O.; Bencini, R. A study of polymorphism in milk proteins from local and imported dairy sheep in Australia by capillary electrophoresis. LWT-Food Sci. Technol. 2006, 39, 63-69. [CrossRef]

78. Silanikove, N. Effects of heat stress on the welfare of extensively managed domestic ruminants. Livest. Prod. Sci. 2000, 67, 1-18. [CrossRef]

79. West, J.W. Effects of heat-stress on production in dairy cattle. J. Dairy Sci. 2003, 86, 2131-2144. [CrossRef]

(C) 2018 by the authors. Licensee MDPI, Basel, Switzerland. This article is an open access article distributed under the terms and conditions of the Creative Commons Attribution (CC BY) license (http:/ / creativecommons.org/licenses/by/4.0/). 